Article

\title{
Air Pollution Dispersion Modelling Using Spatial Analyses
}

\author{
Jan Bitta ${ }^{1,2, *}$, Irena Pavlíková ${ }^{1,2,3}$, Vladislav Svozilík ${ }^{2,3,4}$ and Petr Jančík 1,2,3 \\ 1 Department of Environmental Protection in Industry, Faculty of Metallurgy and Material Engineering, \\ VSB-Technical University of Ostrava, 17.listopadu 15/2172, 70833 Ostrava, Czech Republic; \\ irena.pavlikova@vsb.cz (I.P.); petr.jancik@vsb.cz (P.J.) \\ 2 Institute of Environmental Technology (IET), VSB-Technical University of Ostrava, 17.listopadu 15/2172, \\ 70833 Ostrava, Czech Republic; vladislav.svozilik@vsb.cz \\ 3 Joint Institute for Nuclear Research (JINR), Joliot-Curie 6, 141980 Dubna, Moscow Region, Russia \\ 4 Institute of Geoinformatics, Faculty of Mining and Geology, VSB-Technical University of Ostrava, \\ 17.listopadu 15/2172, 70833 Ostrava, Czech Republic \\ * Correspondence: Jan Bitta, jan.bitta@vsb.cz; Tel.: +420-597-324-324
}

Received: 8 October 2018; Accepted: 15 December 2018; Published: 19 December 2018 updates

\begin{abstract}
Air pollution dispersion modelling via spatial analyses (Land Use Regression-LUR) is an alternative approach to the standard air pollution dispersion modelling techniques in air quality assessment. Its advantages are mainly a much simpler mathematical apparatus, quicker and simpler calculations and a possibility to incorporate more factors affecting pollutant's concentration than standard dispersion models. The goal of the study was to model the $\mathrm{PM}_{10}$ particles dispersion via spatial analyses in the Czech-Polish border area of the Upper Silesian industrial agglomeration and compare the results with the results of the standard Gaussian dispersion model SYMOS'97. The results show that standard Gaussian model with the same data as the LUR model gives better results (determination coefficient $71 \%$ for Gaussian model to $48 \%$ for LUR model). When factors of the land cover were included in the LUR model, the LUR model results improved significantly (65\% determination coefficient) to a level comparable with the Gaussian model. A hybrid approach of combining the Gaussian model with the LUR gives superior quality of results $(86 \%$ determination coefficient).
\end{abstract}

Keywords: pollution dispersion; air quality; land use regression; Symos'97

\section{Introduction}

The PM (particulate matter) is a mixture of both solid and liquid organic and inorganic substances in the air. It mainly consists of sulfates, nitrates, ammoniac salts, soot, mineral particles, metals, bacteria, pollens and water. Particles of diameters smaller than $10 \mu \mathrm{m}\left(\mathrm{PM}_{10}\right)$ have severe health effects because they may get into lungs or even join the blood stream [1-3].

\subsection{Particulate Pollution}

Natural $\mathrm{PM}_{10}$ sources are forest fires, dust storms, volcanic processes, erosion or sea water [4,5]. A large part of $\mathrm{PM}_{10}$ has an anthropogenic origin [6]. It consists of combustion processes (thermal power plants, heating, internal combustion engines), industrial processes like coking, blast furnaces, steelworks, sinter plants, cement production or mineral extraction, dust resuspension from roads and agriculture (soil erosion) [1,7-9]. Recent research indicates non-existence of a minimal threshold concentration value for human health effects [4]. Factors influencing health effects are particles' size and geometry, their chemical composition, physical properties, concentration and time of exposure. 
Particles greater than $10 \mu \mathrm{m}$ are caught by ciliated epithelium of upper respiratory tract and have low health impact. Particles smaller than $10 \mu \mathrm{m}$ cumulate in the bronchi and lungs and cause health issues. Particles smaller than $1 \mu \mathrm{m}$ possess the biggest health threat because they may get into alveoli and frequently contain adsorbed carcinogenic substances. The $\mathrm{PM}_{10}$ inhalation damages mainly heart and lungs and is a cause of premature death of people with heart or lung disease, cancer, fibrosis, allergic reactions, asthma, lung insufficiency, heart attacks, respiratory tract irritation and cough [1-5]. There are two legal pollution limits for $\mathrm{PM}_{10}$. The 24-h average limit is $50 \mu \mathrm{g} / \mathrm{m}^{3}$ which can be exceeded no more than 35 times per year. The annual average concentration limit is set as $40 \mu \mathrm{g} / \mathrm{m}^{3}$ [10,11].

\subsection{Land Use Regression Modelling}

The Land Use Regression (LUR) modelling is an empirical modelling approach which is based on multivariate linear regression. It combines pollution monitoring data with spatial variables describing vicinity of monitoring sites which are typically obtained via spatial analyses in Geographic Information Systems (GIS). The result of the analyses is the linear model

$$
[\text { Pollution }]=[\text { Coef_0 }]+[\text { Coef_1 }] *[\text { Factor_1 }]+[\text { Coef_2 }] *[\text { Factor_2 }]+\ldots+[\text { Coef_n } n *[\text { Factor_ } n]
$$

where $[$ Factor $-*]$ are selected spatial factors and [Coef_*] are regression coefficients obtained from the linear regression analysis at the pollution monitoring sites. The empirical model can be then used to estimate spatial distribution of the $\mathrm{PM}_{10}$ pollution in the area of interest. The LUR model was first used for air pollution monitoring in the SAVIAH (Small Area Variations in Air quality and Health) project. This approach was used to study $\mathrm{NO}_{\mathrm{x}}$ concentrations in three European cities, Amsterdam, Huddersfield and Prague. The successful application of the LUR in the SAVIAH project model spurred its usage in further studies in European countries and in the rest of the world [12-14]. Recently the LUR model has been applied on the $\mathrm{PM}_{10}$ pollution in the USA [15], Mexico [16] or China [17].

\subsection{Gaussian Dispersion Modelling}

Gaussian dispersion models assume an emission transport from continuous pollution sources in a homogenous wind field without specific spatial limits. In the model, the transport is captured in the wind convection and also via turbulence diffusion, which is described statistically by Gaussian distribution. Spatial limitations, mainly terrain, are included in the model by correction coefficients. Gaussian dispersion models are commonly used for long term (i.e., annual) average concentrations modelling. The dispersion is calculated for a set of standard meteorological conditions and summed, weighted by probability of occurrence of such conditions. The most commonly used Gaussian dispersion models are CALINE 3 [18], ADMS-Urban [19] and AERMOD [20]. Caline 3 air pollution model is used for line sources modelling [18]. ADMS-Urban is focused on air pollution modelling in urban areas [19]. AERMOD is a replacement of ISC 3. AERMOD is able to model widespread areas [20]. The air quality in the EU is monitored by the EEA, which publishes the air pollution data regularly. The air quality data are accessible via the Copernicus Atmospheric Monitoring Service (CAMS) [21]. The SYMOS'97 model [22] is a reference pollution dispersion model in the Czech Republic. It is a Gaussian model which calculates pollution dispersion of both gaseous and particulate pollutants from point, linear and area pollution sources. The model takes into account both dry and wet deposition as well as chemical reactions during transport.

\subsection{Objectives and Hypothesis}

The study has two main objectives. The first objective is to compare results of the LUR and the Gaussian dispersion model. The Gaussian dispersion model uses more detail description of the pollution source data as well as the effect of terrain on the pollution dispersion. The LUR model which uses just pollution source data is supposed to have worse quality of results than the Gaussian dispersion model. The Gaussian dispersion does not count with the effect of the land cover on the 
$\mathrm{PM}_{10}$ concentration as it is possible in the LUR model. It is unclear which approach gives better results. The second objective is to use the LUR technique to improve results of the Gaussian dispersion model with the land cover data. This approach should significantly improve the performance of the model.

\section{Data Sources}

All data used are relevant to the year 2010. The study area was selected to match the area of the Air Silesia project [23]. The Air Silesia project was focused on collecting the air pollution data and assessment of the air quality in the border region of the Upper Silesian industrial region. The following Figure 1 shows the study area and the annual mean $\mathrm{PM}_{10}$ concentrations $\left[\mu \mathrm{g} / \mathrm{m}^{3}\right]$ at the pollution monitoring stations.

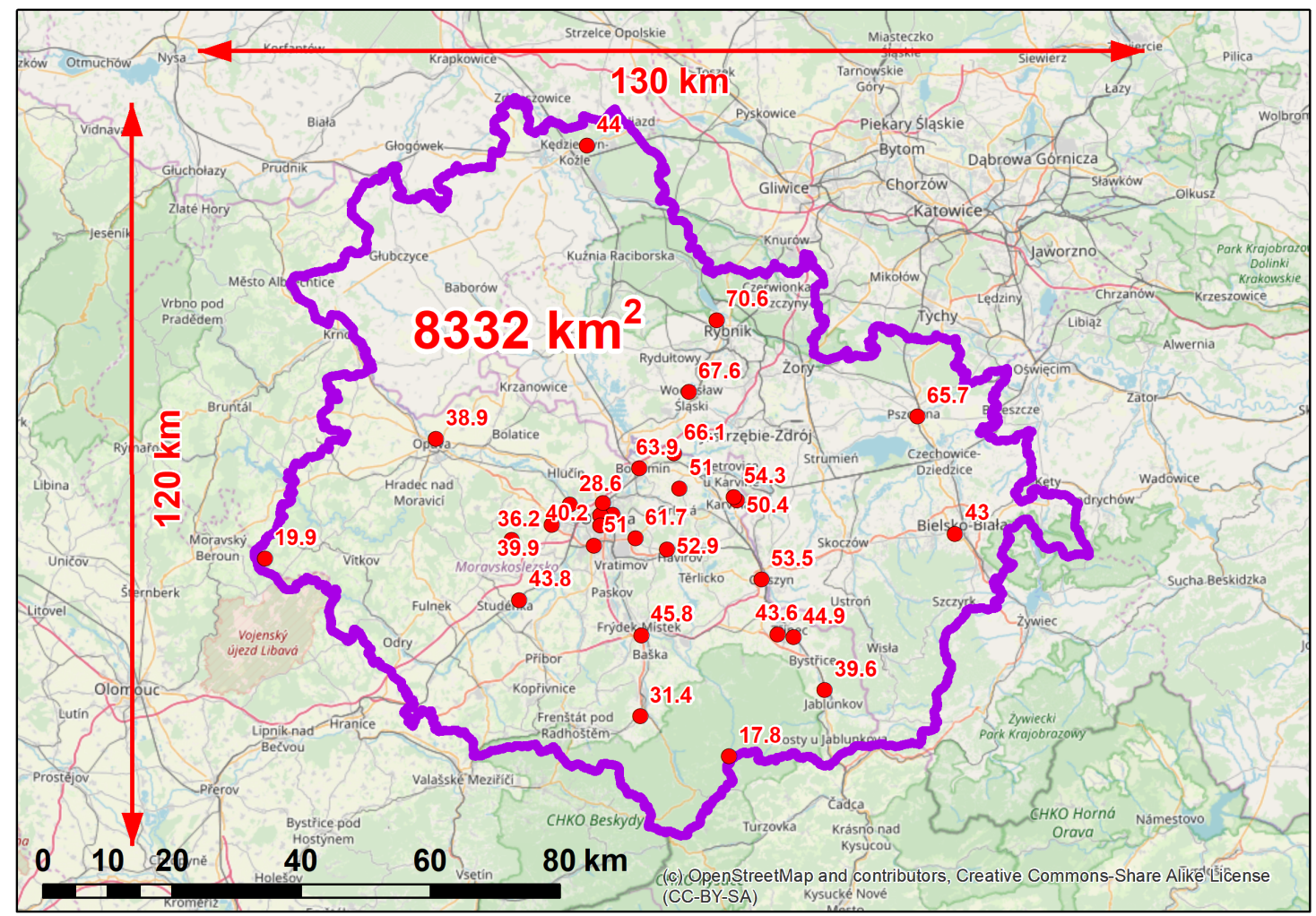

Figure 1. The study area and pollution monitoring stations with annual average of $\mathrm{PM}_{10}$.

There are 2.5 million inhabitants in the study area, which is one of the most air polluted regions of the EU (Figure 2). The most severe pollutants in the region are particulates, polyaromatic hydrocarbons $(\mathrm{PAH})$ and heavy metals (As, $\mathrm{Cd}, \mathrm{Hg}$ ). High level of pollution concentrations are determined by the combination of several key factors; namely, high population density, presence of heavy industries (coal mining and processing, iron and steel production, heavy chemistry), coal energetics (utility and industrial scale to domestic use scale) and unfavorable basin-like terrain configuration. 


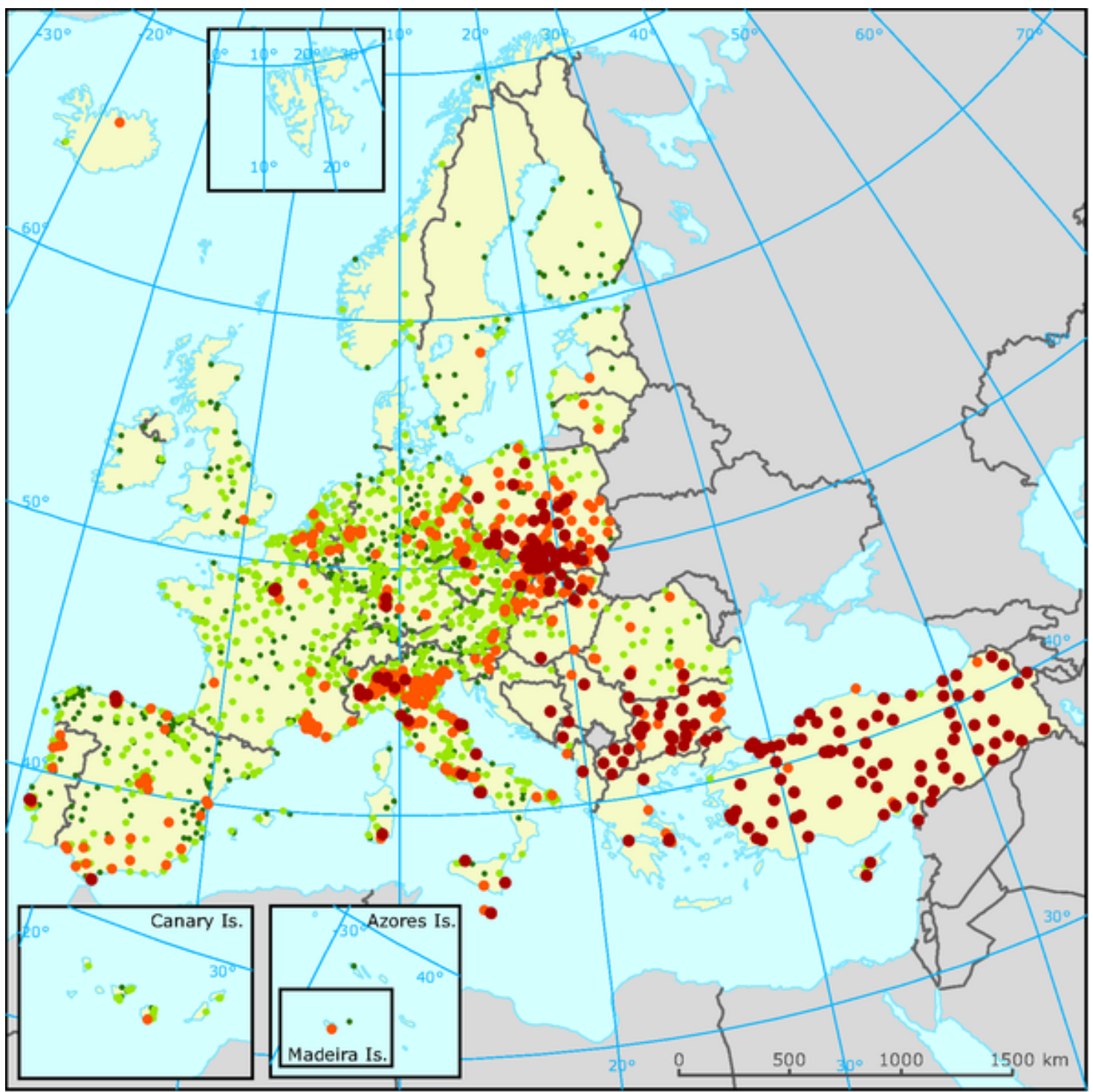

\section{Annual mean particulate matter $\left(\mathrm{PM}_{10}\right)$ 2010, based on daily average with percentage of valid measurements $\geq 75 \%$ in $\mathbf{~ g g} / \mathrm{m}^{3}$}

- $\leq 20 \cdot 20-31 \cdot 31-40 \cdot>40$

Countries/regions not included in the data exchange process

Figure 2. Annual mean $\mathrm{PM}_{10}$ concentrations in 2010 [24].

\subsection{Air Pollution Data}

The air pollution data, presented as yearly averages of $\mathrm{PM}_{10}$ concentrations, were obtained from the yearbooks [25] of the Czech Hydrometeorological Institute and the Voivodship Inspectorate of the Environmental Protection of Silesian Voivodship [26]. There were 27 air pollution monitoring stations measuring the $\mathrm{PM}_{10}$ concentrations in the study area (Figure 1). 


\subsection{Pollution Source Data}

The pollution source data were obtained from the pollution source database provided by the Air Silesia project. The data were divided by the country of origin (Czech-Polish) and by the kind of the pollution source (industrial, domestic heating, car traffic). Industrial sources are represented as a point sources, the input data contain position, average emission flow, height, exhaust diameter, speed, volume flow and temperature of exhaust gases. Domestic heating was represented by the area sources which were squares of a 200-m size-containing position, average emission flow and height. Car traffic sources were modelled as linear sources with length $\leq 50 \mathrm{~m}$ containing line description, average emission flow and height. Brief statistics of emissions are presented in following Table 1 and emission squares (Figure 3).

Table 1. The $\mathrm{PM}_{10}$ pollution sources in the study area, (Air Silesia, 2013).

\begin{tabular}{lccc}
\hline Country & Pollution Sources & No. of Sources & Emissions [t/y] \\
\hline \multirow{3}{*}{ Czechia } & Industrial & 2025 & 2315 \\
& Domestic heating & 21824 & 1589 \\
& Car traffic & 56057 & 961 \\
\hline \multirow{3}{*}{ Poland } & Industrial & 1598 & 13400 \\
& Domestic heating & 33301 & 8610 \\
& Car traffic & 55745 & 911 \\
\hline
\end{tabular}

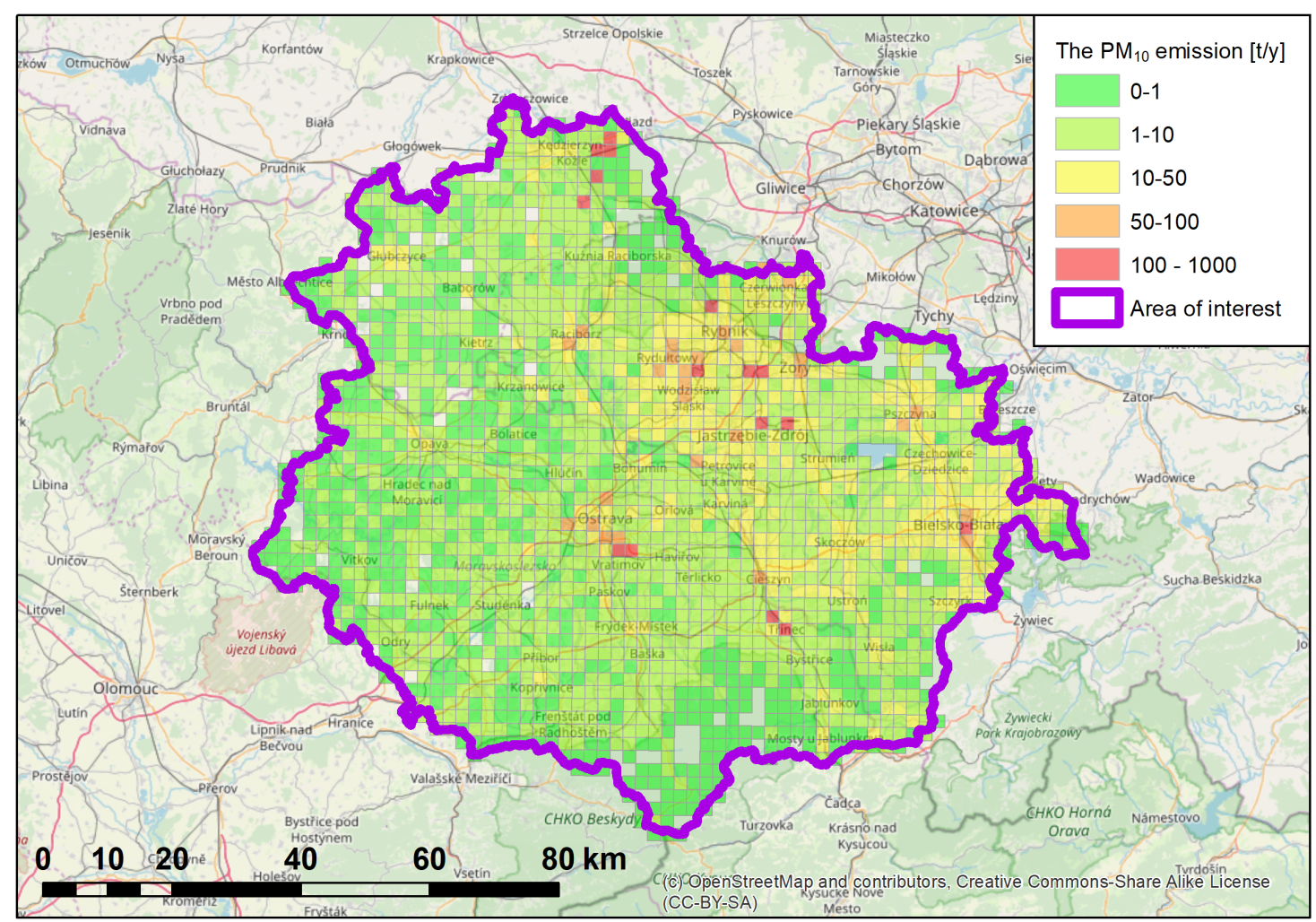

Figure 3. The $\mathrm{PM}_{10}$ emission distribution in the study area, Basemap: OpenStreetMap.

\subsection{Gaussian Model Results}

The Gaussian model results were obtained from the Air Silesia project. There was a long term SYMOS'97 used in the project. Meteorological conditions are standardized by the wind speed (low, medium, strong), wind direction (eight directions + calm) and the atmospheric stability (Bubník-Koldovský classification, five classes) in the long term model. Every combination of meteorological parameters is calculated separately and the annual average concentration is calculated 
as a mean of these values weighted by the probability of occurrence of such weather conditions [22]. The pollution source data enters the modelling in the form described in the section above.

\subsection{Land Use Data}

The land use data were obtained from the CORINE Land Cover dataset [27] as vector datasets. There were four kinds of land cover selected for the analysis, built-up areas, forested areas, areas with grass cover and open soil-agricultural areas.

\section{Methodologies and Results}

There were two basic groups of factors considered in the study; factors of pollution sources and factors of land cover. Each factor (except the distance to the nearest major road) was calculated in the similar fashion. There was a buffer of the selected perimeter created around each of the pollution monitoring stations. The factor was than calculated as a sum, percentage or length-weighted average of the vector data cut by the buffer. Factors were calculated uniformly $(U)$ or they were calculated as a weighted average based on the wind direction probability $(\mathrm{W})$. The area of modelling was split into 14 areas according to the terrain configuration. Meteorological conditions in each area were represented in its own dataset (Figure 4). In that case, the buffer zones were split into 8 slices representing 8 wind directions. Factors were calculated for each slice area and the final weighted factors were calculated as a weighted average of those factors. Weights were the probability of the wind blowing from its corresponding direction. All considered factors are listed in Table 2.

Table 2. Factors of pollution sources, factors of land cover.

\begin{tabular}{ccccc}
\hline Factor & Identifier & Distances & Weighing & Unit \\
\hline Emissions from industrial sources & IS & $100,200,500,1000,2000$ & $\mathrm{U}, \mathrm{W}$ & $\mathrm{t} / \mathrm{y}$ \\
\hline Length of roads & $\mathrm{LR}$ & $100,200,500,1000,2000$ & $\mathrm{U}, \mathrm{W}$ & $\mathrm{m}$ \\
\hline $\begin{array}{c}\text { Average traffic intensity } \\
\text { weighted by length of road sections }\end{array}$ & $\mathrm{TI}$ & $100,200,500,1000,2000$ & $\mathrm{U}, \mathrm{W}$ & $\mathrm{car} /$ day \\
\hline Emissions from domestic heating & $\mathrm{DH}$ & $100,200,500,1000,2000$ & $\mathrm{U}, \mathrm{W}$ & $\mathrm{t} / \mathrm{y}$ \\
\hline Distance to the nearest road & $\mathrm{NR}$ & & $\mathrm{m}$ & \\
\hline Grass covered land & $\mathrm{GCL}$ & $100,200,500,1000,2000$ & $\mathrm{U}, \mathrm{W}$ & $\%$ of area \\
\hline Forested land & FL & $100,200,500,1000,2000$ & $\mathrm{U}, \mathrm{W}$ & $\%$ of area \\
\hline Built-up land & $\mathrm{BL}$ & $100,200,500,1000,2000$ & $\mathrm{U}, \mathrm{W}$ & $\%$ of area \\
\hline Open soil & OSL & $100,200,500,1000,2000$ & $\mathrm{U}, \mathrm{W}$ & $\%$ of area \\
\hline
\end{tabular}

For the purpose of the study, all factors were encoded. For example, the [FL_500_W] code means the factor of forested land cover counted for the buffer distance of $500 \mathrm{~m}$ and weighted by the wind direction probability distribution. 


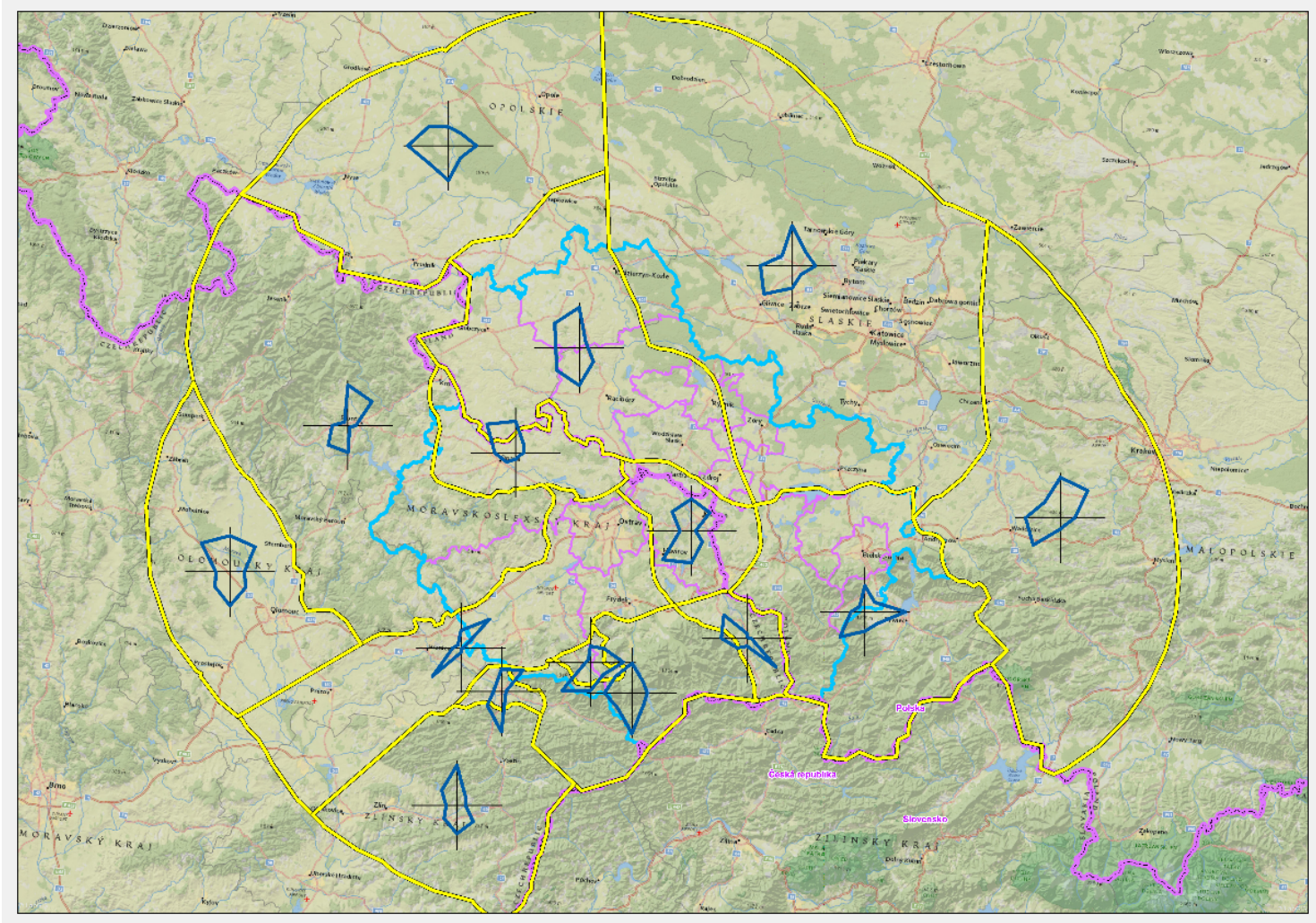

Figure 4. Wind direction probability distribution, (Air Silesia, 2013).

Regression analyses were performed in the Statgraphics software. The regression models were constructed for combinations of industrial sources $\left(\left[I S_{-} *_{-} *\right]\right)$, traffic intensity $\left(\left[\mathrm{TI}_{-} *_{-} *\right]\right)$, domestic heating $\left(\left[D H_{-} * h b o x_{-} *\right]\right)$ and the nearest road $([N R])$. The regressions consisted of two steps, the statistical significance/insignificance of each factor was evaluated and the regression coefficients were calculated with the statistically significant factors. The best statistical analysis result was a regression model:

$$
\begin{array}{r}
{\left[P M_{10 \_} \text {concentration }\right]=30.8507+0.00789643 *\left[I S \_2000 \_W\right]+0.000583609 *\left[T I \_2000 \_W\right]} \\
+0.214567 *\left[D H \_2000 \_W\right]+0.01368 *[N R]
\end{array}
$$

The $\mathrm{R}^{2}$ of the model is $48 \%$ and the root of the mean square error (RMSE) of the model is $10.59 \mu \mathrm{g} / \mathrm{m}^{3}$. Correlation of input parameters was in the $-0.08-0.21$ interval. When the factors of the land cover were taken into account, the resulting best linear model was constructed as

$$
\begin{array}{r}
{\left[P M_{10 \_} \text {concentration }\right]=46.3802+0.00113242 *\left[I S \_2000 \_W\right]+} \\
+203484 *\left[D H \_2000 \_W\right] \\
-0.299948 *\left[F L \_1000 \_W\right]
\end{array}
$$

The $\mathrm{R}^{2}$ of the model is $65 \%$ and the RMSE of the model was $8.34 \mu \mathrm{g} / \mathrm{m}^{3}$. Correlation of input parameters was in the $-0.33-0.32$ interval. Observed to predicted values comparison is in following Figure 5. 


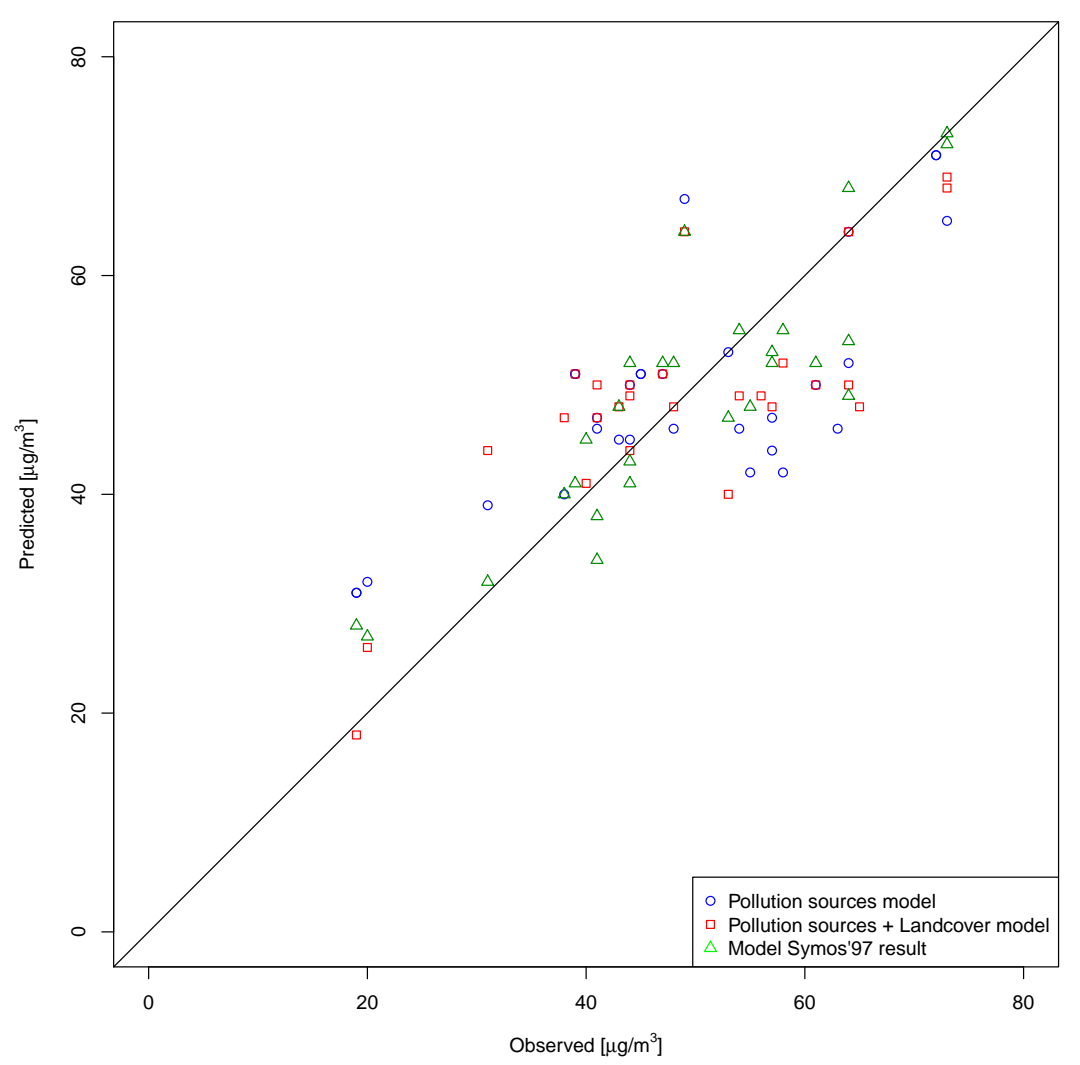

Figure 5. Observed to predicted comparison of results.

The results of the SYMOS'97 model were statistically evaluated with the measurements at monitoring sites. The $\mathrm{R}^{2}$ of the model is $71 \%$ and the RMSE of the model was $7.44 \mu \mathrm{g} / \mathrm{m}^{3}$. Correlation of input parameters was in the 0.14-0.42 interval. Both approaches, the LUR and the dispersion model, can be combined into a hybrid, two-step process where the dispersion model results are used as an input data for the LUR model construction. There were two possible inputs tested. The land cover data were combined with both the partial results of the model and the sum of all partial results (Table 3).

Table 3. Factors based on dispersion model.

\begin{tabular}{ccc}
\hline Pollution from industrial sources & M_IS & $\mu \mathrm{g} / \mathrm{m}^{3}$ \\
\hline Pollution from domestic heating & M_DH & $\mu \mathrm{g} / \mathrm{m}^{3}$ \\
\hline Pollution from road traffic & M_RT & $\mu \mathrm{g} / \mathrm{m}^{3}$ \\
\hline Sum of all sourcesc & M_SUM & $\mu \mathrm{g} / \mathrm{m}^{3}$ \\
\hline
\end{tabular}

When the dispersion model results and the factors of the land cover were taken into account, the resulting best linear model was constructed as

$$
\begin{aligned}
{\left[P M_{10 \_} \text {concentration }\right]=} & 28.7086+0.155629 *\left[O S L \_1000 \_W\right]-0.12583 *\left[F L \_1000 \_W\right] \\
& +3.50718 *\left[M \_I S\right]+3.25479 *\left[M \_D H\right]+6.75771 *\left[M \_R T\right]
\end{aligned}
$$

The $\mathrm{R}^{2}$ of the model was $86 \%$ and the RMSE of the model was $5.56 \mu \mathrm{g} / \mathrm{m}^{3}$. Correlation of input parameters was in the $-0.56-0.42$ interval. Observed to predicted values comparison is in following Figure 6. 
The dispersion model provides more accurate information about pollution dispersion from pollution sources and the LUR model allows incorporation of additional variables.

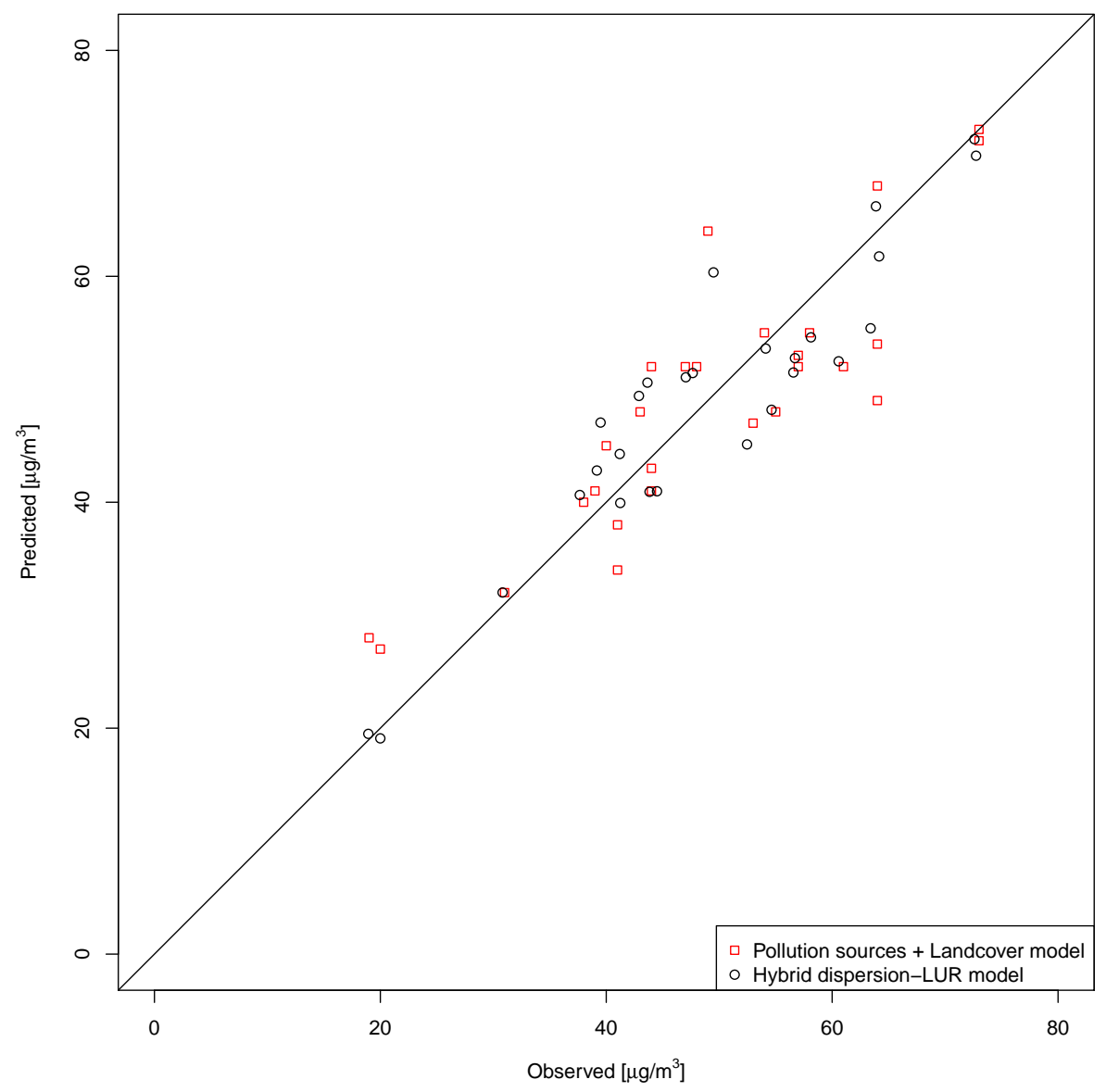

Figure 6. Observed to predicted comparison of results.

\section{Discussion}

With similar input data, the LUR model gives much worse results than the Gaussian dispersion model $\left(\mathrm{R}^{2} 48 \% \times 71 \%\right)$. The LUR model was providing better estimates of the air pollution when the pollution monitoring station was positioned within the urban environment in the vicinity of air pollution sources. On the other hand, predictions at rural and natural sites were inaccurate because the model, as constructed, is not able to take into account the long distance pollution transport. The long distance transport can be represented only as a constant value which is a part of the absolute coefficient of the linear LUR model. The LUR model also did not take into account other parameters of pollution sources used in Gaussian models, mainly source height, exhaust gas speed and temperature, speed and fluency of the traffic stream, etc. The pollution dispersion is also described more accurately in the Gaussian models in the form of non-linear dispersion formulas. The LUR model with added land cover factors gives better predictions of $\mathrm{PM}_{10}$ concentrations $\left(\mathrm{R}^{2} 65 \%\right)$. The result of the LUR model is fully comparable with the results of previous studies which are 0.36-0.82 in [12], 0.58 in [17], 0.66-0.76 in [15] and 0.59 [16]. A direct comparison cannot be done because these studies constructed LUR models for different sets of input variables, time scales and may be focused just on the urban environment. The quality of the result is comparable with the Gaussian model. The Gaussian model provided generally better results in industrial and urban-background monitoring sites while the LUR model with land cover factors outperformed it slightly at the rural and natural monitoring sites. The LUR model was also able to explain the reason of the significant $\mathrm{PM}_{10}$ concentration underestimation by Gaussian model at three monitoring sites (Opava-Kateřinky, Věřňovice, Studénka). The LUR model 
showed that all three sites which are positioned close to the edge of urban areas are heavily influenced by the nearby agricultural activities and/or wind-caused reemissions and erosion represented in the LUR model by the Open soil factor. When the dispersion and the LUR model were combined, the resulting Gaussian-LUR hybrid model kept more accurate information about pollution dispersion from pollution sources of the Gaussian model and was able to incorporate the effect of land cover on the $\mathrm{PM}_{10}$ concentrations via the consecutive LUR model approach. This resulted in much improved quality of the dispersion model $\left(\mathrm{R}^{2} 86 \%\right)$. The comparison of the spatial distribution of pollution obtained via the Gaussian model and via the combined Gaussian-LUR model (Figure 7) shows significantly different result showing a significance of the land cover on $\mathrm{PM}_{10}$ concentrations. The Gaussian model seems to overestimate the $\mathrm{PM}_{10}$ concentrations in both urban (parks, green belts) and natural environments (forests) because of the effect of tree cover. The Gaussian model also underestimates the $\mathrm{PM}_{10}$ concentrations in croplands. According to the results of the study, the tree cover reduces the $\mathrm{PM}_{10}$ pollution by up to $12.5 \mu \mathrm{g} / \mathrm{m}^{3}$ in the urban environment and by up to $28.14 \mu \mathrm{g} / \mathrm{m}^{3}$ in the rural environment. The combined Gaussian-LUR model formula also gives extra information. The road traffic emissions seem to be underestimated by a factor of 2 , this may be caused by the reemission of particulates which was not accounted for in the model.

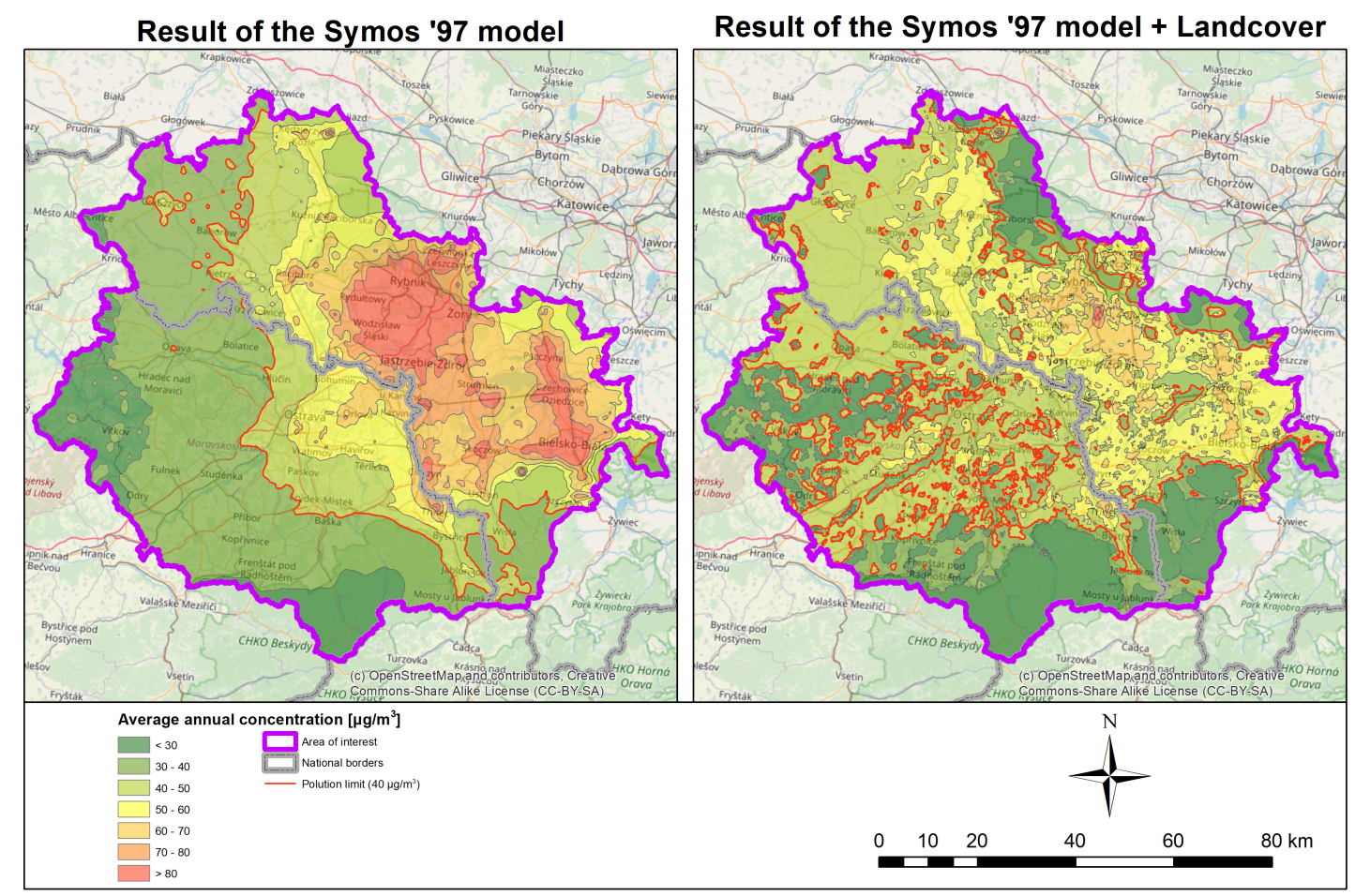

Figure 7. Comparison of model results' spatial distribution.

\section{Conclusions}

We were able to develop a combination of the Gaussian dispersion model with the LUR model which to the authors' knowledge has not been performed yet. The combined Gaussian-LUR model was able to improve the quality of modelling significantly in comparison with both separate approaches applied on the test case scenario. The developed modelling technique needs to be tested further and improved in order to be able to provide generally applicable formulas and algorithms. The authors intend to apply the experience gained during this research on the data and results of the Air Tritia project [28] which will be completed in 2020. The goal of the Air Tritia project is to assess the air quality in whole Upper Silesian region and in the three years of the study. 
Author Contributions: Data curation, J.B.; Formal analysis, J.B.; Funding acquisition, P.J.; Investigation, I.P.; Methodology, J.B.; Project administration, V.S.; Writing-review \& editing, V.S.

Funding: This work was financially supported by the Ministry of Education, Youth and Sports of the Czech Republic in the "National Feasibility Program I", project LO1208 "Theoretical Aspects of Energetic Treatment of Waste and Environment Protection against Negative Impacts". This research was supported by the "Interreg CENTRAL EUROPE", Uniform approach to the air pollution management system for functional urban areas in Tritia region/Air Tritia (CE1101) which is co-financed from the European Regional Development Fund.

Acknowledgments: Access to computing and storage facilities owned by parties and projects contributing to the National Grid Infrastructure MetaCentrum, provided under the programme "Projects of Large Research, Development, and Innovations Infrastructures" (CESNET LM2015042), is greatly appreciated. This research was supported in part through computational heterogenous cluster "HybriLIT" provided by The Laboratory of Information Technologies, Joint Institute for Nuclear Research in Dubna, Moscow region, Russia.

Conflicts of Interest: The founding sponsors had no role in the design of the study; in the collection, analyses, or interpretation of data; in the writing of the manuscript, and in the decision to publish the results.

\section{Abbreviations}

The following abbreviations are used in this manuscript:

$\begin{array}{ll}\text { PM } & \text { Particulate Matter } \\ \text { LUR } & \text { Land Use Regression } \\ \text { US EPA } & \text { United States Environmental Protection Agency } \\ \text { WHO } & \text { World Health Organization } \\ \text { GIS } & \text { Geographic Information Systems } \\ \text { SAVIAH } & \text { Small Area Variations in Air quality and Health } \\ \text { PAH } & \text { Polycyclic Aromatic Hydrocarbons } \\ \text { CHMI } & \text { Czech Hydrometeorological Institute } \\ \text { EEA } & \text { European Environment Agency }\end{array}$

\section{References}

1. Obroučka, K. Ochrana ovzduší I.: Látky znečišt'ující ovzduší; VŠB-TU Ostrava: Ostrava, Czech Republic, 2003.

2. World Health Organisation. Ambient (Outdoor) Air Quality and Health. 2017. Available online: http: / / www.who.int/mediacentre/factsheets/fs313/en/ (accessed on 12 January 2017).

3. United States Environmental Protection Agency. Particulate Matter (PM) Basics. 2017. Available online: https: / / www.epa.gov / pm-pollution/particulate-matter-pm-basics (accessed on 12 January 2017).

4. Aus DEE. Australian Government: Department of the Environment and Energy. Particulate Matter (PM10 and PM2.5). 2017. Available online: http:/ / www.npi.gov.au/resource/particulate-matter-pm10-and-pm25 (accessed on 12 January 2017).

5. Integrovaný Registr Znečišt'ování. Polétavý Prach (PM10). 2017. Available online: http://www.irz.cz/ node/85 (accessed on 12 January 2017).

6. Zajusz-Zubek, E.; Mainka, A.; Korban, Z.; Pastuszka, J.S. Evaluation of highly mobile fraction of trace elements in PM10 collected in Upper Silesia (Poland): Preliminary results. Atmos. Pollut. Res. 2015, 6, 961-968. [CrossRef]

7. Francová, A.; Chrastný, V.; Šillerová, H.; Vítková, M.; Kocourková, J.; Komárek, M. Evaluating the suitability of different environmental samples for tracing atmospheric pollution in industrial areas. Environ. Pollut. 2016, 220, 286-297. [CrossRef] [PubMed]

8. Grynkiewcz-Bylina, B.; Rakwic, B.; Pastuszka, J.S. Assessment of Exposure to Traffic-Related Aerosol and to Particle-Associated PAHs in Gliwice, Poland. Pol. J. Environ. Stud. 2015, 14, 117-123.

9. Pavlíková, I.; Jančík, P. Metallurgical source-contribution analysis of annual average concentration: A dispersion modeling approach in Moravian-Silesian region. Metalurgija 2013, 52, 497-500.

10. Zákon č. 201/2012 Sb., o ochraně ovzduší. In Sbírka Zákonů; 2 May 2012. Available online: https:// portal.gov.cz/app/zakony / zakonPar.jsp?idBiblio=77678\&nr=201 2F2012\&rpp=15\#local-content (accessed on 12 January 2017). 
11. Vyhláška č. 330/2012 Sb. o způsobu posuzování a vyhodnocení úrovně znečištění, rozsahu informování veřejnosti o úrovni znečištění a při smogových situacích. In Sbírka Zákonů; 8 October 2012. Available online: https: / / portal.gov.cz/app/zakony / zakonPar.jsp?idBiblio=78340\&nr=330 2F2012\&rpp=15\#localcontent (accessed on 12 January 2017).

12. Hoek, G.; Beelen, R.; De Hoogh, K.; Vienneau, D.; Gulliver, J.; Fischer, P.; Briggs, D. A review of land-Use regression models to assess spatial variation of outdoor air pollution. Atmos. Environ. 2008, 42, 7561-7578, doi:10.1016/j.atmosenv.2008.05.057. [CrossRef]

13. Kryza, M.; Szymanowski, M.; Dore, A.J.; Werner, M. Application of a land-Use regression model for calculation of the spatial pattern of annual NOx air concentrations at national scale: A case study for Poland. Procedia Environ. Sci. 2011, 7, 98-103. [CrossRef]

14. Li, L.; Wu, J.; Wilhelm, M.; Ritz, B. Use of generalized additive models and cokriging of spatial residuals to improve land-Use regression estimates of nitrogen oxides in Southern California. Atmos. Environ. 2012, 55, 220-228. [CrossRef] [PubMed]

15. Masiol, M.; Zíková, N.; Chalupa, D.C.; Rich, D.Q.; Ferro, A.R.; Hopke, P.K. Hourly land-use regression models based on low-cost PM monitor data. Environ. Res. 2018, 167, 7-14. [CrossRef]

16. Son, Y.; Osornio-Vargas, Á.R.; O’Neill, M.S.; Hystad, P.; Texcalac-Sangrador, J.L.; Ohman-Strickland, P.; Meng, Q.; Schwander, S. Texcalac-Sangrador, Pamela Ohman-Strickland, Qingyu Meng, Stephan Schwander, Land use regression models to assess air pollution exposure in Mexico City using finer spatial and temporal input parameters. Sci. Total Environ. 2018, 639, 40-48. [CrossRef]

17. Liu, W.; Li, X.; Chen, Z.; Zeng, G.; León, T.; Liang, J.; Huang, G.; Gao, Z.; Jiao, S.; He, X.; et al. Land use regression models coupled with meteorology to model spatial and temporal variability of NO2 and PM10 in Changsha, China. Atmos. Environ. 2015, 116, 272-280. [CrossRef]

18. Benson, P. CALINE3-A Versatile Dispersion Model for Predicting Air Pollutant Levels Near Highways and Arterial Streets; Technical Report; US EPA: Washington, DC, USA, 1979.

19. ADMS. Cambridge Environmental Research Consultants. ADMS-Urban Model. 2017. Available online: http:/ / www.cerc.co.uk/environmental-software/ADMS-Urban-model.html (accessed on 12 January 2017).

20. AERMOD. Aermod: Description of Model Formulation. United States Environmental Protection Agency I US EPA. 2014. Available online: https://www3.epa.gov/scram001/7thconf/aermod/aermod_mfd.pdf (accessed on 1 January 2018).

21. The Copernicus Atmosphere Monitoring Service (CAMS). The Copernicus Atmosphere Monitoring Service. 2018. Available online: http:/ / https:/ / atmosphere.copernicus.eu/ (accessed on 1 January 2018).

22. Bubník, J.; Keder, J.; Macoun, J. SYMOS 97—Systém Modelování Stacionárních Zdrojů; Český Hydrometeorologický ústav: Praha, Czech Republic, 1998; ISBN 80-85813-55-6.

23. Air Silesia. Air Silesia-Výstupy. 2013. Available online: http://www.air-silesia.eu/cz/a1170/V_stupy.html, (accessed on 12 January 2017).

24. European Environment Agency. Annual Mean Particulate Matter $\left(\mathrm{PM}_{10}\right)$ 2010, Based on Daily Average with Percentage of Valid Measurements $\geq 75 \%$ in $\mu \mathrm{g} / \mathrm{m}^{3}$. 2013. Available online: http:/ / www.eea.europa.eu/ data-and-maps/figures/annual-mean-particulate-matter-pm10 (accessed on 12 January 2017).

25. ČHMÚ. Znečištění Ovzduší a Atmosférická Depozice v Datech, Česká Republika 2010. 2011. Available online: http:/ / portal.chmi.cz/files/portal/docs/uoco/isko/tab_roc/2010_enh/cze/index_CZ.html (accessed on 12 January 2017).

26. WIOŚ Katowice. Informacje o Stanie środowiska w Województwie śląskim w 2010 roku. 2013. Available online: http:/ / www.katowice.pios.gov.pl/index.php?tekst=monitoring/informacje/stan2010/i (accessed on 12 January 2017).

27. European Environment Agency. CORINE Land Cover. 2015. Available online: http://www.eea.europa.eu/ publications/COR0-landcover (accessed on 12 January 2017).

28. Air TRITIA. Air TRITIA—Interreg Central Europe. 2018. Available online: http:/ /www.interreg-central.eu/ Content.Node/AIR-TRITIA.html (accessed on 11 January 2018).

(C) 2018 by the authors. Licensee MDPI, Basel, Switzerland. This article is an open access article distributed under the terms and conditions of the Creative Commons Attribution (CC BY) license (http:/ / creativecommons.org/licenses/by/4.0/). 